Б азально-клеточный рак на фоне невуса сальных желез: клиническая картина и дифференциальная диагностика

Ю.В. Карачева, Т.Н. Гузей, Т.А. Яковлева, А.Н. Смыкова, Ю.Ю. Винник

ГБОУ ВПО «Красноярский государственный медицинский университет им. проф. В.Ф. Войно-Ясенецкого» Минздрава России

660022, г. Красноярск, ул. Партизана Железняка, д. 1

Представлено описание двух клинических случаев базально-клеточного рака кожи, развившегося на фоне невуса сальных желез. В статье отражены клинические особенности и критерии диффференциальной диагностики пигментной формы базально-клеточного рака кожи.

Ключевые слова: базально-клеточный рак кожи, невус сальных желез, меланома.

Контактная информация: julkar19@yandex.ru. Вестник дерматологии и венерологии 2016; (5): 51—54.

\title{
B asal cell skin cancer with sebaceous glands nevus: clinical presentation and differential diagnostics
}

\author{
Y.V. Karacheva, T.N. Guzey, T.A. Yakovleva, A.N. Smykova, Y.U. Vinnik
}

Krasnoyarsk State Medical University named by prof. V.F. Voyno-Yasenetsky Partizana Zheleznyaka str., 1, Krasnoyarsk, 660022, Russia

The description of two clinical cases of basal cell skin cancer, which developed against the background of a nevus of sebaceous glands. The article reflects the clinical features and criteria for the differential diagnosis of pigmented form of basal cell skin cancer.

Key words: basal cell carcinoma of the skin, nevus of sebaceous glands, melanoma. 
Базально-клеточный рак (БКР) - наиболее распространенная злокачественная опухоль кожи с местнодеструирующим ростом, но без тенденции к метастазированию. В структуре немеланомных опухолей кожи на долю БКР приходится до 98,8\% всех новообразований в этой группе [1].

В России частота БКР составляет 267,8 на 100000 населения. Большая частота рецидивов, увеличение числа первично множественных форм ставят это заболевание в ряд важнейших проблем дерматоонкологии [2].

БКР может развиться de novo или реже на участках кожи, поврежденных химическими, термическими и другими фракторами. Очевидна провоцирующая роль УФ-облучения, причем не имеет значения давность избыточной инсоляции. БКР может возникнуть на фоне позднего рентгеновского дерматита, пигментной ксеродермы, очагов рубцовой атрофии при туберкулезной и красной волчанке. Для базалиом характерен иммунодефицит с преимущественным поражением клеточного звена, сопровождающимся достоверным уменьшением иммунорегуляторного индекса CD4/CD8 [3, 4].

Преимущественная локализация БКР отмечается на коже открытых участков тела. В 83\% случаев опухоль развивается на коже головы, при этом 96,48\% из них - на коже лица $[1,5,6]$.

В мировой литературе описаны случаи развития БКР на невусе сальных желез Ядассона (НСЖЯ), а также сочетание его с другими опухолями придатков кожи [7-10]. НСЖя является врожденной кожной гамартомой, характеризующейся гиперплазией сальных желез и встречающейся у 0,3\% новорожденных на коже лица и шеи. НСЖЯ представлен мелкими желтоватыми бляшками при рождении, которые к пубертату увеличиваются в размерах и формируют бородавчатые разрастания. Невус сальных желез имеет опухолевый потенциал для развития кожных неоплазий, не ограничивающихся сальной дифрференцировкой [8-10]. В.А. Молочков и соавт. описывали БКР на фоне НСЖЯ, указывая в своих исследованиях, что 2 случая БКР из 2085 развились на НСЖЯ. По мнению Y. Lever, базалиома на фоне НСЖЯ развивается не вследствие злокачественной дегенерации, а в результате снижения диффреренцировки первичных эпителиальных зародышевых клеток и последующего повышения их пролиферативной активности. Эту точку зрения автор подтверждает тем, что, несмотря на развитие в раннем возрасте, невусассоциированные базалиомы редко достигают крупных размеров, исключительно редко проявляют агрессивные черты и тем более склонность к метастазированию [7, 9]. Такеши Намики и соавт. описали ассоциацию БКР, папиллярной сирингоцистаденомы и трихофолликуломы с невусом Ядассона у 67-летней женщины, что свидетельствует о плюрипотент- ности невуса сальных желез для апокриновой, сальной и фолликулярной диффреренцировки [8].

На кафедре дерматовенерологии КрасГМУ за последние 15 лет было диагностировано 2 случая БКР на невусе сальных желез. В обоих случаях развивались пигментные узелковые фрормы БКР, которые приходилось дифференцировать с меланомой кожи.

\section{Случай 1}

Больная Р.С. 60 лет, проживает в Красноярске, не работает. Обратилась 20.04.2015 с жалобами на высыпания на коже правой щеки. Анамнез заболевания: с рождения у больной высыпания в виде узелков телесного цвета, расположенных линейно. Дерматологами ставился диагноз невуса сальных желез, в 2013 г. двукратно проводилась криодеструкция элементов. В октябре 2014 г. на невусе сальных желез появился узелок черного цвета до 5 мм в диаметре, безболезненный. Больная была направлена на кафедру дерматовенерологии с курсом косметологии и ПО им. В.И. Прохоренкова КрасГМУ им. проф. В.Ф. Войно-Ясенецкого на консультацию с целью уточнения диагноза. Локальный статус: на коже правой щеки линейный очаг, представленный папулами телесного цвета с атрофией по центру, на которой папула до 8 мм в диаметре черного цвета с гладкой поверхностью (рис. 1). Дерматоскопическое исследование выявило серо-голубоватые пятна в центре образования, по периферии которых определялись древовидные сосуды. На основании данных анамнеза, локального статуса и дерматоскопической картины был поставлен диагноз: базальноклеточный рак на фоне невуса сальных желез. Больная направлена в Краевой онкологический диспансер для иссечения образования.

Онкологами при поступлении больной был поставлен клинический диагноз узловатой формы меланомы кожи, с которым больная была направлена на опера-

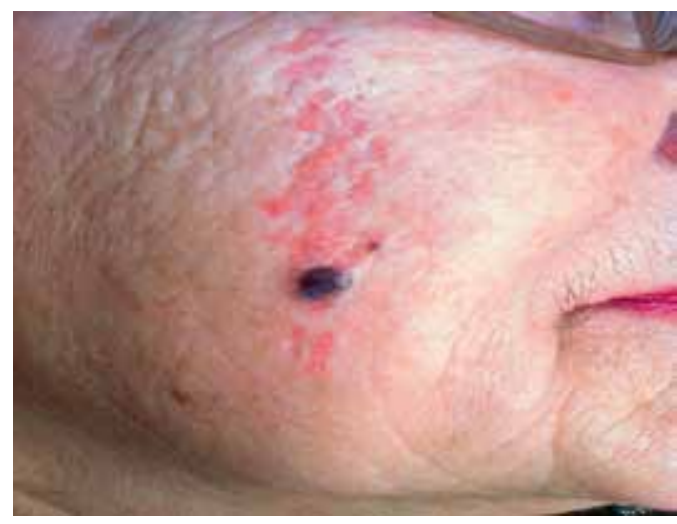

Рис. 1. БКР (пигментная фрорма) на невусе сальных желез. Больная Р.С. 60 лет 
тивное лечение в дневной стационар Красноярского онкологического диспансера. Гистологическая картина биоптата кожи: в дерме гиперплазия сальных желез (рис. 2), среди которых определяются солидные тяжи опухолевых базалоидных клеток с пигментом как в опухолевых клетках, так и в меланофагах дермы (рис. 3). Заключение: гистологическая картина базально-клеточного рака пигментной формы на фоне невуса сальных желез.

Озлокачествление невуса сальных желез у пациентки может быть связано с неоднократной криодеструкцией образования.

\section{Случай 2}

Больная С.И. 45 лет, базально-клеточный рак на фроне невуса сальных желез также развился после механической травмы (этот клинический случай был нами описан в журнале «Клиническая дерматология и венерология», №3 от 2007 г.). 15.03.2004 больная С.И., жительница Красноярска, обратилась с жалобами на высыпания на коже лба, существующие с рождения. За три года до обращения после травмы (ударилась лбом об угол стола) на поверхности очага появились 2 узелка черного цвета (рис. 4). При осмотре: на коже лба бляшка $5 \times 4$ см, представленная множественными папулами телесного цвета с сальным блеском, склонными к слиянию. По периферии бляшки единичные милиарные папулы. В центральной части образования 2 узелка черного цвета размером 0,5 × 0,5 и 0,8 × 0,5 см плотноэластической консистенции. При контактной микроскопии узелков выявлены серо-голубые пятна и древовидные сосуды, свидетельствующие о БКР кожи. С диагнозом базально-клеточный рак, пигментная фрорма на фоне невуса сальных желез больная была направлена в Краевой онкологический диспансер, где было проведено хирургическое иссечение кожного образования с пластикой свободным кожным лоскутом. Онкологами при поступлении поставлен кли-

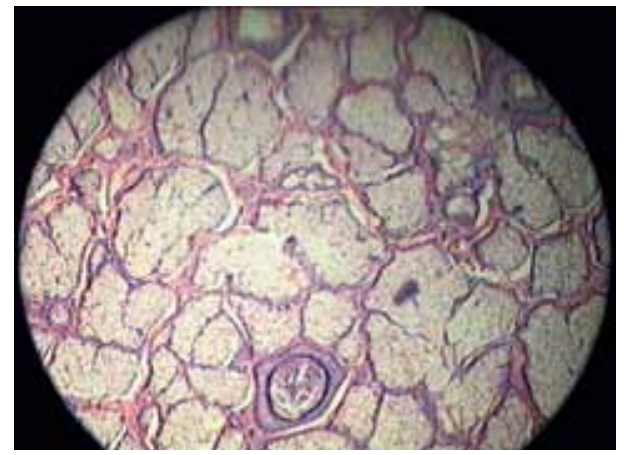

Рис. 2. Гиперплазия сальных желез.

Здесь и на рис. 3 и 5: окраска гематоксилином и эозином, $\times 200$ нический диагноз меланомы кожи, и лишь гистологическое исследование образования подтвердило пигментную фрорму БКР кожи (рис. 5).

Таким образом, несмотря на то что развитие БКР на фоне невуса сальных желез встречается до-

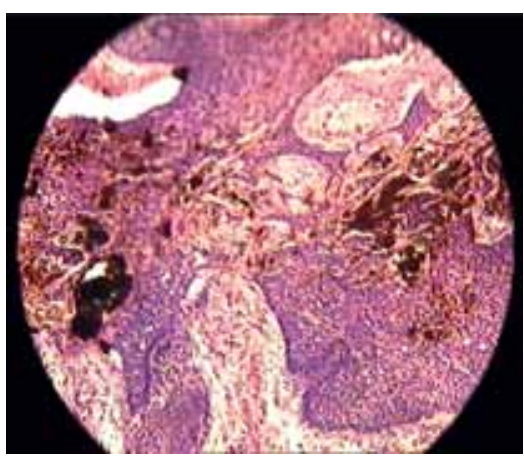

Рис. 3. В дерме опухолевые тяжи базалоидных клеток с включениями пигмента



Рис. 4 Два узла пигментной формы БКР на невусе Рис. 4. сальных желез у больной С. И. 45 лет

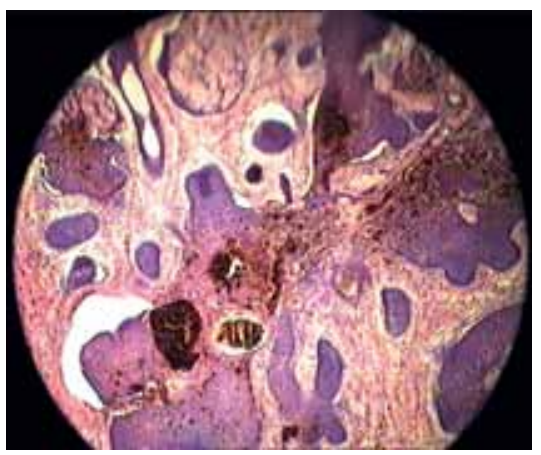

Рис. 5. Солидные опухолевые тяжи из базалоидных клеток, содержащие пигмент 
вольно редко, клиницистам следует проявлять онкологическую настороженность в отношении пороков развития кожи. Дерматоскопическое исследование - неинвазивный метод диагностики in vivo, значительно улучшающий диагностику невоклеточных, немеланоцитарных, доброкачественных и злокачественных образований кожи. Серо-голубые пятна при дерматоскопии встречаются как при базалиоме, так и при меланоме, но наличие древовидных сосу- дов и отсутствие признаков невоклеточного образования (пигментная сеть, полоски, глобулы) в обоих клинических случаях позволили на ранних этапах диффреренциальной диагностики заподозрить БКР. Клинические случаи приведены в связи с редкостью данной патологии, которая представляет существенную сложность в диагностике, и необходимостью проведения диффференциальной диагностики с меланомой кожи.
1. Kubanova A.A., Kubanov A.A., Kondrahina I.N., Gribanov N.V. Photodynamic of the surface form of basalioma and actinic keratosis with the topical dministration of methyl aminolevulevulinate. Vestn dermat venereol 2015; (4): 105-112. [Кубанова А.А., Кубанов А.А., Кондрахина И.Н., Грибанов Н.В. Фотодинамическая терапия поверхностной формы базальноклеточного рака кожи и актинического кератоза с топическим применением метиламинолевулината. Вестн дерматол венерол 2015; (4): 105-112.]

2. Pobilat A.E., Prokhorenkov V.I., Arutunan G.A. Aktual'nye voprosy dermatoonkologii: basal,nokletohnyi rak kozhi $v$ Krasnoyarskom krae. Dermatoonkologya 31-33. [Побилат А.Е., Прохоренков В.И., Арутюнян Г.А. Актуальные вопросы дерматоонкологии: базально-клеточный рак кожи в Красноярском крае. Дерматоонкология 31-33.]

3. Pobilat A.E., Prokhorenkov V.I., Karacheva Y.V., Batuxtin E.N. Gigantskie basaliomy. Klin dermatol venerol 2009; 1: 37—40. [Побилат А.Е.,

\section{Литература}

Прохоренков В.И., Карачева Ю.В., Батухтин Е.Н. Гигантские базалиомы. Клин дерматол венерол 2009; 1: 37-40.]

4. Rodionov A.N., Raznatovskii K.I., Dermatologia, rukovodstvo dla vrachei. Sankt-Petersburg 2006; 183. [Родионов А.Н., Разнатовский К.И. Дерматогистопатология. Руководство для врачей. Санкт-Петербург 2006; 183.]

5. Dubenskij V.V., Dubenskij Vi.V. Novoobrazovaniya kozhi v praktike dermatovenerologa. Voprosy ehpidemiology, ehtiopatogenesa i diagnostiki. Vestn dermatol venereol 2008; (6): 22-40]. [Дубенский В.В., Дубенский Вл.В. Новообразования кожи в практике дерматовенеролога. Вопросы эпидемиологии, этиопатогенеза и диагностики. Вестн дерматол венерол 2008; (6): 22—40.]

6. Volgin V.N., Sokolova T.V., Kolbina M.S., Sokolovskaya A.A. Basalno-kletochnyj rak kozhi: ehpidemiologiya, patogenes, klinicheskaya kartina (chast 1) Vestn dermatol venereol 2013; (2): 6-14. [Волгин В.Н., Соколова Т.В., Колбина М.С., Соколовская А.А. Базально- клеточный рак кожи: эпидемиология, патогенез, клиническая картина (часть 1). Вестн дерматол венерол 2013; (2)]: 6—14.]

7. Molochkov V.A., Mardi H. K rasvitiyu basaliomy na fone nevusa salnyx gelez Yaddasona. Almanax klinicheskoi mediciny 2007; (15): 232235. [Молочков В.А., Марди Ш. К развитию базалиомы на фоне невуса сальных желез Ядассона. Альманах клинической медицины 2007: (15): 232-235.]

8. Takeshi Namiki, Keiko Miura, Makiko Ueno, Yumi Arima, Aya Nishizawa, and Hiroo Yokozekia. Four Different Tumors Arising in a Nevus Sebaceous, Case Rep Dermatol 2016 Jan-Apr; 8 (1): 75-79.

9. Lever W., Schaumburg G. Tumours of the epidermal appendages. In: Lever W., Schaumburg G., editors. Histopathology of the skin. 7th ed. Philadelphia: Lippincott 1990; 594—6.

10. Chun K., Vazquez M., Sanchez J.L. Naevus sebaceous: Clinical outcome and consideration for prophylactic excision. Int J Dermatol 1995; 34: 538-41.

об авторах:

Ю.В. Карачева - д.м.Н., зав. кафедрой дерматовенерологии с курсом косметологии и ПО им. проф. В.И. Прохоренкова

ГБОУ ВПО КрасГМУ им. проф. В.Ф. Войно-Ясенецкого Минздрава России

Т.Н. Гузей — к.м.н., доцент кафедры дерматовенерологии с курсом косметологии и ПО им. проф. В.И. Прохоренкова

ГБОУ ВПО КрасГМУ им. проф. В.Ф. Войно-Ясенецкого Минздрава России

Т.А. Яковлева - к.м.н., доцент кафедры дерматовенерологии с курсом косметологии и ПО им. проф. В.И. Прохоренкова ГБОУ ВПО КрасГМУ им. проф. В.Ф. Войно-Ясенецкого Минздрава России

А.Н. Смыкова - к.м.н., ассистент кафедры дерматовенерологии с курсом косметологии и ПО им. проф. В.И. Прохоренкова ГБОУ ВПО КрасГМУ им. проф. В.Ф. Войно-Ясенецкого Минздрава России

Ю.Ю. Винник - д.м.н., доцент кафедры урологии, андрологии и сексологии ГБОУ ВПО КрасГМУ им. проф. В.Ф. ВойноЯсенецкого Минздрава России

\section{Конфликт интересов}

Авторы заявляют об отсутствии потенциального конфликта интересов, требующего раскрытия в данной статье 